\title{
An Evaluation of Corporate Governance Disclosure in Ghanaian and Nigerian Banks
}

\author{
${ }^{1}$ Araniyar C. Isukul, ${ }^{2}$ John J. Chizea \\ ${ }^{1}$ Department of Banking and Finance, Rivers State University of Science and Technology, \\ Npkolu, P.M.B. 5080, Port Harcourt, Rivers State, Nigeria \\ ${ }^{2}$ Department of Economics, Baze University, Plot 686 Cadastral Zone, Abuja, Nigeria
}

\begin{abstract}
Corporate governance disclosure has become the buzz word for countries in developing economies, with the spate of corporate governance failures and the need to prevent a continuation of this trend. There has been the call for developing countries to enhance and improve on corporate governance disclosure practices. This study examines corporate governance disclosure in Ghanaian and Nigerian Banks using the un-weighted disclosure index technique. This research analyses corporate governance disclosure practices in the annual reports of 10 listed banks in Ghanaian and Nigerian banks in the year 2014. The findings of the research reveal that Ghanaian and Nigerian banks comply with several codes and principles of corporate governance disclosure: with Ghanaian banks having a lower level of disclosure than their Nigerian counterparts. On closer inspection, both Ghanaian and Nigerian banks have poor scores in voluntary corporate governance disclosure. Ghanaian banks tend to be worse off, as the level of variation in levels of corporate governance disclosure is higher than Nigerian banks. In comparison, Nigerian banks on the average tend to have better voluntary disclosure practices than Ghanaian banks. Also, Ghanaian and Nigerian banks include some elements of corporate social responsibility reporting in their annual reports. The research recommends that policymakers and regulators should devise policies targeted at enhancing voluntary corporate governance disclosure and increasing board diversity in the boardrooms.
\end{abstract}

Keywords: Corporate Governance Disclosure, developing countries, Agency Theory, Stakeholder Theory, Corporate Social Responsibility

\section{INTRODUCTION}

Corporate governance can simply be defined as a system or mechanism by which companies are directed and controlled (Cadbury, 2002). This explanation can be regarded as a narrow definition of corporate governance where the focus of corporate governance is restricted to the roles of two principal actors - the shareholders and the managers. While a narrow definition may be suitable in explaining corporate governance in developed countries, a narrow definition falls short in explaining corporate governance in developing countries (Oyejide\&Soyibo, 2001). The simple reason is that several institutions and establishments necessary for ensuring effective corporate governance such as political infrastructure, the rule of law, an independent media and regulatory enforcement mechanism are either weak or ineffective (Adegbite\& Nakajima, 2012). Consequently, a broader definition of corporate governance is sought, one that takes into inclusion the peculiar nature of corporate governance in developing countries (Solomon, 2010). In doing so, corporate governance would include 'the whole set of legal, cultural and institutional arrangements that determine what public corporations can do, who controls them, how that control is exercised, and how the risks and returns from the activities they undertake are allocated' (Blair, 1995). 
An essential mechanism for ensuring that corporate governance activities of firms are kept within the ambits of the law, in terms of transparency and accountability is corporate governance disclosure (Patel \& Dallas, 2002). For developing and emerging economies, a series of corporate governance scandals in Europe, America and Asia has brought to the fore the need for improving and enhancing corporate governance disclosure (Nenova, 2005). The adoption of a series of corporate governance reforms in countries such as Ghana and Nigeria were all targeted at enhancing corporate governance practices, transparency and disclosure (Tsamenyi et al., 2007; Okapara, 2009). For any financial and stock market to perform effectively, it is crucial that firms enlisted in these markets disclose information in an adequate and timely manner to boost both shareholders' and investors' confidence (Healy \&Palepu, 2001; Abdelkarim et al., 2009). In making crucial investment decisions, shareholders and investor need to be armed with the timely and relevant information on the price and the value of financial market securities (Eng\&Mak, 2003). In corporate governance, a disclosure of information is considered an integral ingredient and instrument that is essential for financial markets to operate efficiently (Marston \& Shrives, 1991; Beeke\& Brown, 2006).

Previous research studies in developing countries have examined disclosure practices in different political and socio-economic settings aimed at increasing our knowledge and understanding of the dynamics of disclosure practices. In general, corporate governance disclosure in developing countries is hampered by its institutional configurations such as weak legal and regulatory mechanisms, lower disclosure standards, ineffective enforcement capabilities, political interference in corporate activities, and a weak and ineffective board (Oyejide\&Soyibo, 2001; Barako, 2007; Samaha\&Dahawy, 2010). To date, there is a paucity of research on corporate governance disclosure in developing countries (Akhtaruddin, 2005; Bhasin, 2010; Humayun\&Adelepo, 2012). The few papers published have focused extensively on single country studies. This research intends to go beyond the investigation of a single country study by investigating corporate governance disclosure practices in Nigerian and Ghanaian Banks.

Consequently, the purpose of this research is to investigate corporate governance disclosure practices of Ghanaian and Nigerian banks so as to gain insight into the nature of corporate governance disclosure of the banks. In addition, this paper seeks to find answers to the following questions: to what extent do Nigerian and Ghanaian banks disclose information in their annual reports? What is the nature of the information disclosed, do Ghanaian banks disclose more information than Nigerian banks? What is the level of corporate governance voluntary disclosure of Ghanaian and Nigerian banks? What is the level of compliance in corporate governance disclosure of Ghanaian and Nigerian banks? This paper's contribution to the research in corporate governance in developing countries is in the comparative analysis of disclosure in Ghanaian and Nigerian banks. Most research in corporate governance disclosure in developing countries are single case studies; this research goes beyond the single case typology to examine corporate governance disclosure practices in two different countries.

\section{AGENCY THEORY}

The bulk of the research papers that have explored, examined and investigated corporate governance disclosure have largely been drawn from the agency theoretical framework (Healy \&Palepu, 2001; Brennan \& Solomon, 2008). Agency theory posits that agency problem arises as a result of shareholders (principals) delegating the responsibility of running the firms to managers (agents). This bequeathing of most decision-making responsibility by shareholders to managers may cause conflicts in the interest of the principals and agents (Cohen, Krishnmurty\& Wright, 2004). Shareholders tend to be focused on maximizing shareholder value and shareholder wealth, while managers are inclined to pay more attention to activities of a firm that increase their personal wealth (Jensen \&Meckling, 1976). Consequently, the conflicts and tension caused by divergence of interest may result in agency costs. Agency costs 


\author{
Araniyar C. Isukul, John J. Chizea \\ An Evaluation of Corporate Governance Disclosure in Ghanaian and Nigerian Banks
}

can be described as the value loss that results from shareholders not exercising direct control of their corporation (Eisenhardt, 1989).

To resolve these conflicts of interest, shareholders have put in place some policy prescription measures that have been designed to reduce, minimize and align principal/agent interest (Guilding et al., 2005). Benchmarking managerial remuneration or executive pay to selected performance criteria indicators is a means of minimizing agency costs; it ensures that managers earn more as a result of creating wealth for their shareholders (Fama\& Jensen, 1983; Schotter\&Wiegelt, 1992). Other effective methods that can be applied is measures targeted at enhancing transparency and corporate governance disclosure because they contribute to protecting of shareholders' interest as it promotes accountability and gives credibility to the dependability of the financial reports (Boatright, 1999; Gomez-Mejia \& Wiseman, 2007). However, there are criticisms of the agency theory within the corporate governance for developing countries literature, for its failure to take into consideration the institutional infrastructure that influences business activities within this environment (Isukul\&Chizea, 2015).

\title{
2.1 Stakeholder Theory
}

Stakeholder theory was developed as a result of the weaknesses in agency theory (Hill \& Jones, 1992). Agency theory is seen as constrictive; its basic concern is with maximizing shareholders' value to the detriment of other critical stakeholders has been questioned (Donaldson \& Davis, 1991). Surely, the purpose of the firm extends beyond the creating of shareholder value and the pecuniary benefits that shareholders will gain from their investments in the firm (Reynold et al., 2006; Boss et al., 2009). While maximizing the wealth of shareholders is considered of significant import, the stakeholder theory argues that shareholders are not the only critical stakeholder a firm or business needs to attend to (Freeman, 2010). There are other stakeholders whose needs have to be addressed too, they include employees, government agencies, customers, suppliers and local community (Philips, 2003). Failure to address the needs of various stakeholders may pose a significant non-economic threat to the continuity of the business. For example, companies that engage in drilling and mining who have failed to comply with the necessary health and safety guidelines in executing their business have had to pay hefty fines for damaging the environment. At the core of the stakeholder theory is the need to identify, understand and manage the needs and interests of various stakeholders (Solomon, 2010).

From a distance, agency theory and stakeholder theory may appear to contradict each other, they make look like they have no common ground, but on closer inspection, there does seem to be some similarities between both of them (Strand \& Freeman, 2015). For one, they are both focused on creating value - value for shareholders or value for stakeholders (Solomon, 2010). In addition, stakeholder theory maintains that firms can only attain long-term profitability when it meets the needs of the various stakeholders. Profitability is seen as a byproduct of effectively managing stakeholder relationships. Stakeholder theory is not without its limitation. The stakeholder theory posits that it is possible to identify, manage, and balance the needs of various interest groups (Bosse et al., 2009). In reality, this is not easily achieved; on occasion, the needs of various interest groups may clash, and the resources to meet the needs of all the interest groups may not always be available.

\section{A REVIEW OF THE RESEARCH ON CORPORATE GOVERNANCE IN DEVELOPING COUNTRIES}

There is a particular narrative which runs through the literature on corporate governance in developing countries, that weak institutions have a significant influence on corporate governance practices (Ahunwan, 2002; Okike, 2007; Isukul\&Chizea, 2015). Corporate governance practices in developing countries tend to be hampered by the lack of institutional 


\section{Araniyar C. Isukul, John J. Chizea \\ An Evaluation of Corporate Governance Disclosure in Ghanaian and Nigerian Banks}

infrastructure that is necessary to maintain, promote and enforce good corporate governance culture (Okpara, 2009; Young, 2010). The works of La porta (1997) and Klapper and Love (2002) maintain that the legal environment matter, countries with functional legal institutions and strong investor's protection are inclined to have better larger capital markets. The opposite also holds true, countries with weak legal institutions, and poor investor's protection which tend to have a smaller financial capital market. These institutional weaknesses have inadvertently have created a difficult and harsh environment for businesses to operate and have significantly driven up the costs of business operations for most firms operating in developing countries (Adegbite, 2015). As such, businesses operating in developing countries are forced to provide many basic social infrastructures taken for granted in developed countries (Yakasai, 2001).

Also, the ownership structure in developing countries is skewed towards family ownership (Chen et al., 2008; Jabeen\& Shah, 2011). While family owned, business is not without its own strengths, it does pose significant agency costs to the business (Bhasin, 2010). These costs result from the following issues: management entrenchment and shareholder misappropriation of business funds and altruistic behavior (Tsamenyi et al., 2007). Research on family ownership structure does reveal problems of information asymmetry. These problems tend to provide for family members, who are mostly controlling shareholders, the opportunity to redirect and channel resources from profitable business ventures to resolve their personal matters at unfair prices (Samaha\&Dahawy, 2010). Consequently, by so doing, they intentionally reduce the propensity of minority shareholders to earn and gain expected returns from their investments (Humayun and Adelepo, 2012). Furthermore, there is no distinction between family and company assets, governance-related policies as a rule are normally informal and can lead to the reliance on key family personnel instead of structures and processes. Thus, it does accelerate the possibility of insider business trading and dealings which tend to weaken corporate governance practices of the firm.

While family ownership does present a challenge to corporate governance in developing countries, there are deeper cultural and social issues that are negatively influencing corporate governance in developing countries (Nenova, 2005). The literature on corporate governance in developing countries has identified some cultural and social factors that include: the extended family syndrome, where members of extended family persistently seek financial support from family members that are considered well off (Tsamenyi et al., 2007). Hence, it may encourage unethical practices such as embezzlement of funds. Tribalism, nepotism, and sexism rank high on the list, all influence the selection process; they ensure that the best candidate suitable for the job may lose out if he/she does not fit into the particular mold the employer is seeking (Ahunwan, 2002). This consequently entrenches mediocrity in corporate governance practices. These systemic, socio-cultural and economic problems do signify serious problems that need to be addressed; failure to do so could result in worsening a pathetic situation. So far, reforms at addressing poor corporate governance practices in developing countries have sought to adopt and implement the international best practice. Adegbite and Nakajima (2012) maintain that such an approach is likely to fail. Rather, they suggest that the solution to corporate governance in developing countries needs to be examined within an institutional context because cultural norms and belief systems determine the direction and quality of corporate governance.

\subsection{Corporate Governance in Ghana and Nigeria}

Corporate governance practices in Ghana are similar to other developing countries in SubSaharan Africa (Rwegasira, 2000; Singh, 2003; Mensah et al., 2003; Okeahalam\&Akinboade, 2003). The same peculiar constraints that hinder the implementation of good corporate governance practices in developing countries also apply to Ghana (Berglof\& von Thadden, 1999; Claessens \& Fan, 2002; Oman et al., 2003). They can be classified into two broad categories; internal constraints and external constraints. For internal constraints, the lists 


\section{Araniyar C. Isukul, John J. Chizea \\ An Evaluation of Corporate Governance Disclosure in Ghanaian and Nigerian Banks}

include but are not limited to the following, unethical and corrupt business practice, poor transparency and disclosure practices, managerial incompetence and credit constraints (Abor \& Adjasi, 2007; McGee, 2010; Agyemang, \& Castellini, 2013). The external constraints include weak institutional legal and regulatory framework as contained in the Ghanaian Company Code of 1969, political interference in the running of public companies and a lack of vibrant shareholders and weak protection for minority shareholders (Okeahalam \& Akinboade, 2003; Kyereboah-Coleman \& Biekpe, 2008). To deal with the issues of poor corporate governance practices in Ghana, several policy measures have been introduced to reform, restructure and improve corporate governance. Some of the notable reforms include privatization of stateowned enterprises to make them more efficient and profit-oriented and an introduction of corporate governance codes targeted at improving corporate governance practices among listed firms (Kyereboah-Coleman \& Biekpe, 2008). For Ghanaian banks sector, specific policy reforms include recapitalization of the minimum capital base for the banks, revisions of the Bank Act, 2004 (Act 673), and the introduction of deposit insurance schemes in 2014. The reform measures taken were meant to strengthen the capital base of the banks, strengthen investors' confidence and protect depositors' funds.

As earlier stated, the corporate governance practices in developing countries including Nigeria are plagued by similar problems: political meddlesomeness in corporate governance activities, weak regulatory enforcement capability, poor institutional facilities for protection of minority shareholders and a lack of institutional infrastructure such as power generation, functional road network and regulatory enforcement mechanisms (Oyejide \& Oyibo, 2001; Ahunwan, 2002; Adegbite, 2015). All these institutional and internal weaknesses have created a hostile business environment, but has also escalated the costs of doing business and consequently made most Nigerian business uncompetitive (Uchendu, 2005; Okike, 2007). With the reform of Nigerian political culture and a return of government from military to a civilian regime, there have been several concerted efforts to deepen corporate governance practices in Nigeria (Gunu, 2009; Adegbite \& Nakajima, 2012). A series of market-oriented reforms saw the privatization and deregulation of state-owned enterprises such as the telecommunication, electric and gas companies (Ogbeche \& Koufopolous, 2007; Adekoya). The banks and financial industries were not left out. In the banks, recapitalization of the minimum base forced mergers and acquisitions for those banks who failed to recapitalize within the specified period which shrunk the total number of banks from 89 to 24 (Soludo, 2006). Also, the central bank of Nigeria put in place a cashless policy that was intended to increase the number of available financial payment instruments such as credit and debit cards, automated teller machines, as well as other cashless platforms for banking transactions (mobile phone and internet banking).

\subsection{Research on Corporate Governance Disclosure}

Corporate governance disclosure research, in most part, has focused on issues, concerns and problems of disclosure in developed countries (Wallace, 1988; Radebaugh \& Gray, 1993; Haniffa \& Cooke, 2002). Research in disclosure has looked at some of the important determinants of disclosure such as board size, ownership structure, return on asset, firmspecific characteristics, and independence of directors (Adhikari \& Tondkar, 1992; Gray et al., 1995; Barako, 2007). The findings are at best mixed, with some research maintaining that size of the board, ownership structure, and return of asset can have some influence on the levels of disclosure (Elmaghri, Mohamed, Ntim, Collins \& Wang, 2016;). Other studies tend to find conflicting results that suggest that corporate governance committees, institutional ownership, and managerial ownership do not have a significant influence on the levels of disclosure (Lambert, Luez, \& Verrechhia, 2007; Core, Hail, \& Verdi, 2014).

In the last ten years, research on disclosure has moved beyond determinants of disclosure to an increasing interest in voluntary corporate governance compliance (Arvidsson, 2003; Elshandidy\&Neri, 2015; Melis et al., 2015). Several rational explanations have been given to explain the reasons why firms are increasingly intent on voluntarily disclosing information on 


\author{
Araniyar C. Isukul, John J. Chizea \\ An Evaluation of Corporate Governance Disclosure in Ghanaian and Nigerian Banks
}

their corporate governance practices (Cheng and Courtenay, 2006; Ntim et al., 2016). Recently, theoretical developments in institutional theory have contributed to explaining the growth in the adoption of corporate governance codes (Adegbite, 2015). The institutional theory maintains that institutional influences such as economic, political and social institutions can considerably influence the spread and adoption of business norms and standards (Isukul\&Chizea, 2015).

After the enactment of the Sarbanes-Oxley Act, Abdioglu, et al. (2015) investigated the role of information asymmetry and its influence on firm level disclosure on foreign institutional investors. They wanted to ascertain if the rigorous disclosure requirements enacted by the Sarbane-Oxley Act (SOA) would encourage foreign investments. Their findings reveal that foreign investors increased their equity holdings in American listed firms after the passage of SOA. While mandatory disclosure is responsible for increasing levels of disclosure, the size of the firm can also influence levels of disclosure. Maingot and Zeghal (2008) investigated disclosure practices in Canadian banks on the following issues: board independence, board structure, financial information and corporate social responsibility disclosure. Their findings reveal that the size of the banks matter as larger banks disclosed more information than smaller banks.

While the research on corporate governance disclosure in developed countries is extensive, covering a broad range of issues, the same cannot be said of corporate governance disclosure in developing countries (Barako, 2007; Tsamenyi et al., 2007). The research in disclosure in developing countries tends to mirror that of disclosure in developed countries (Humayun \& Adelepo, 2012). Research in developing countries has also examined determinant of corporate governance disclosure using similar variables such as ownership structure, firm characteristics, and profitability ratios (Agyei-Mensah, 2012).

Thus far, the finding of the research reveals that corporate governance disclosure in developing countries is poor, especially when compared with the levels of disclosure in developed countries (Bhasin, 2013). Barako (2007) investigated the determinants of corporate governance disclosure for Kenyan listed firms. In particular, he focused on the extent to which the following issues influenced disclosure in Kenyan firms: firm characteristics, ownership structure, and corporate governance attributes. The results show that firm characteristics and ownership structure have a significant influence on the levels of corporate governance disclosure. Also, regarding voluntary disclosure, he finds that Kenyan listed firms all have low levels of voluntary corporate governance disclosure. In a similar study on disclosure, Samaha et al. (2012) evaluated the levels of voluntary disclosure practices for Egyptian listed firms. With regards to levels of voluntary disclosure, their findings are similar to that of Barako (2007). However, they did find a significant difference in the levels of disclosure; firms that have a higher number of independent directors had slightly better disclosure scores than firms which did not.

In Ghana, Agyei-Mensah (2012) assessed the levels of disclosure of internal control information of Ghanaian listed firms. The findings indicate that Ghanaian firms' disclosure is low; an estimated 35\% implies that most of the listed firms did not disclose adequate internal control information in their annual reports. However, on a positive note, the results reveal that independence of the board is a significant variable in explaining internal control disclosure. For Nigeria, the results are similar to that of Ghana - Wallace (1988) evaluated corporate governance disclosure of Nigerian listed firms and found low levels of disclosure for Nigerian listed companies with regards to the following issues: valuation methods, balance sheets, and historical items.

\title{
3.3 Characteristics of the Banking Sector in Ghana and Nigeria
}

The Ghanaian banking sector has not always been vibrant and competitive. The banking sector has undergone a series of structural and market-oriented reforms that were intended to 


\section{Araniyar C. Isukul, John J. Chizea \\ An Evaluation of Corporate Governance Disclosure in Ghanaian and Nigerian Banks}

strengthen its competitiveness, bolster the minimum capital base and the enforcement of stringent regulatory and banking supervision. In the past, the Ghanaian banking sector was heavily regimented; government controls had effectively banned the participation of foreign banks and as such only local banks participated in the delivery of banking services. As a result, the banking sector was plagued with a lot of inefficiencies, long customer queues that extended for miles outside the banking offices, a lack of banking innovation and competition that making banking for customers stressful and unpleasant. Presently, the Ghanaian banking sector can be regarded as very competitive with a mix of local and foreign banks actively interacting in the banking space. The market share of the top five banks as at 2014 has been reduced to 39.2 percent when compared to the market share of the top five banks in Nigeria and South Africa which control more than 60 and 80 percent of the market respectively.

As at 2014, the total number of banks in the sector consisted of 28 deposit money banks: 15 foreign-owned banks, 12 local banks, 138 rural and community banks, 503 microfinance banks and 60 Non-bank financial institutions. In a bid to strengthen the banking sector, the minimum capital requirements for entrants of foreign banks and local banks entrance into the Ghanaian banking market had been increased from $\$ 1.9$ to $\$ 16$ million, while the minimum requirement for new universal banks is $\$ 33$ million. Despite the significant strides made in the banking sector, high-interest rates have made it impossible for bank customers to access loans at an affordable rate. Also, the issue of financial deepening is one that needs to be addressed, with a significant amount of the currency issued by the Bank of Ghana resided in the homes of citizens in metal boxes, under beds and buried in the ground.

On a comparative note, the Nigerian banking industry is as diverse as its Ghanaian counterparts. With both having a mix of banking institutions that attend to the needs of the various banking clientele. As at December 2014, there were 24 deposit money banks, 884 microfinance banks, 42 primary mortgage banks, 64 finance companies and six development finance institutions. While there are some similarities between the Nigerian and Ghanaian banks regarding the total number of deposit money banks, there are significant differences that must be highlighted. The minimum capital requirement for banks in Nigeria is $\$ 200$ million, compared to the Ghanaian bank capital requirement of $\$ 16$ million dollars. In terms of penetration of foreign banks and competitiveness, Ghanaian banks outperform Nigerian banks. In Ghana, the numbers of foreign banks are more than the local banks. For Nigeria, the opposite holds true as the number of local banks is more than the foreign banks.

To enhance the banking competitiveness in the Nigerian banks, the Central Bank of Nigeria had introduced several far-reaching structural and regulatory reforms that were as a result of deliberate banking policy response targeted at correcting perceived or imminent banking sector weaknesses. Some of the structural weaknesses identified include the following: the existence of a large number of banks with a weak capital base, non-compliance with regulatory requirements, the banking sectors' heavy reliance on public sector funds, gross insider abuse and bank failure to loan funds to small and medium scale enterprises.

It is worthy of note that the banking reforms have recorded some measure of success with regards to deepening the minimum capital base from $\$ 15$ million to $\$ 200$ million. This has created a measure of financial stability in the banking sector. The introduction of a code of corporate governance has been useful in addressing the ethical issues by providing banks with a guideline and template for the conduct of good behavior. The most recent policy mix focused on the adoption of electronic banking technologies and the transition from a cash-based to a cashless society. Thus far, this policy has achieved mixed results. The platform for banking transactions has increased beyond the borders of the banking halls enabling customers to do business from the convenience of their homes. Still, institutional weaknesses such as epileptic power supply and persistent blackouts constrain the effective utilization of these technologies. 


\subsection{Research Hypothesis}

Based on the research question and the literature review, the research hypotheses were tested:

$\mathrm{H}_{0}{ }^{1}$. There is no difference in the Board Structure, and Directors Profile disclosure in the annual reports of the Ghanaian and Nigerian banks examined.

$\mathrm{H}_{0}{ }^{2}$. There is no difference in the Financial Information, and corporate information disclosure in the annual reports of the Ghanaian and Nigerian banks examined

$\mathrm{H}_{0}{ }^{3}$. There is no difference in the Board Independence, and Board Committee disclosure in the annual reports of the Ghanaian and Nigerian banks examined

$\mathrm{H}_{0}{ }^{4}$. There is no difference in the Corporate Social Responsibility Disclosure in the annual reports of the Ghanaian and Nigerian banks examined

$\mathrm{H}_{0}{ }^{5}$. There is no difference in the Information on website disclosure in the annual reports of the Ghanaian and Nigerian banks examined

$\mathrm{H}_{0}{ }^{6}$. There is no difference in the Remuneration of Board disclosure in the annual reports of the Ghanaian and Nigerian banks examined

\section{METHODOLOGY}

To assess the levels of disclosure of Ghanaian and Nigerian banks, a disclosure index was constructed. To construct the disclosure index, an examination of existing literature enabled the researchers to develop templates that served as guidelines for evaluating the disclosure levels of the annual reports (Buzby, 1974; Marston \& Shrive, 1991). In the finance literature, two methods are used in assessing disclosure: unweighted and weighted disclosure methods (Botosan, 1997). The strength of the unweighted disclosure method lies in the fact that it gives equal importance and consideration to every disclosure item in the annual report, this ensures that the bias that results from giving unequal weighting to disclosure items in the annual report does not occur (Healy \&Palepu, 2001).

This research adopts the use of the unweighted method, as this method is better suited to address the issue of subjectivity bias that results from the usage of the weighted disclosure method. In assessing the disclosure practices of Ghanaian and Nigerian banks' annual reports, a dichotomous scoring approach was employed. A value of 1 was assigned when a particular bank disclosed information on the constructed disclosure index and a value of zero was assigned for non-disclosure. In calculating the disclosure score, the number of items disclosed by the banks in their annual report is divided by the total number of items in the disclosure list.

The total disclosure score for each bank is:

$\mathrm{D}=\sum_{i=1}^{m} d j$

Where $\mathrm{m}=$ the number of items disclosed in the bank's annual reports

$\mathrm{di}=1$ when an item is disclosed in the bank's annual reports

$\mathrm{di}=0$ when an item is not disclosed in the bank's annual report

In classifying the dimensions of corporate governance disclosure, this research draws from and adapts the works of Maingot and Zeghal (2008).

They classify corporate governance disclosure into six types: financial and corporate information, board structure and director profile, corporate social responsibility disclosure, board independence and board committee, remuneration of the board, and information on a website. Furthermore, in complementing the disclosure indices used by Maingot and Zeghal, a few additions were made from the perusal of 5 banks in Ghana (Ghana commercial bank, Royal Bank, Continental Acceptance Limited bank, Unique bank, and Unibank) and 5 banks in Nigeria (Diamond Bank, Fidelity Bank, Eco Bank, First city Monument Bank and Access Bank). 


\section{DISCUSSION OF FINDINGS}

A close scrutiny of Table 1 reveals the board structure of Ghanaian and Nigerian banks are similar in terms of composition and size, although the Nigerian banks tend to have a larger number of directors. There is also a proficient mix of executive and non-executive directors on the boards of Ghanaian and Nigerian Banks. The Ghanaian, Nigerian and the Commonwealth Association for Corporate Governance guidelines recommend the appointment of competent directors who not only add value to the team but are also capable of exercising independent judgment. In general, Ghanaian banks have fewer directors when compared to the Nigerian banks. A total number of directors in the Ghanaian banks is 48 , while that of the Nigerian banks is 68. In relation to non-executive directors, the difference is quite marginal as the total number of non-executive directors is 35 for Ghanaian banks, and 36 for Nigerian banks. With regards to gender diversity, Ghanaian banks have fewer female executives on board when compared to their Nigerian counterparts. In fact, the number of female directors in the Nigerian banks almost doubles their Ghanaian counterparts. However, in terms of board diversity, the Ghanaian and Nigerian boards are both male-dominated with female directors representing less than $25 \%$ of the board. Access Bank can be regarded as the most gender sensitive bank with five female members on board. First City Monument Bank is the least gender sensitive bank with no female member holding an executive board position. With regards to disclosure of a number of board meetings held within the year, only one Ghanaian bank (UniBank) disclosed that information. For Nigerian banks, all the banks disclosed the number of meetings held by the directors within the year.

Table 1: Board Structure, Meetings, and Committees

\begin{tabular}{|l|l|l|l|l|l|}
\hline Company & $\begin{array}{l}\text { Male } \\
\text { Directors }\end{array}$ & $\begin{array}{l}\text { Female } \\
\text { Directors }\end{array}$ & Total & $\begin{array}{l}\text { Non- } \\
\text { Executive } \\
\text { Directors }\end{array}$ & $\begin{array}{l}\text { Board } \\
\text { Meetings } \\
\text { in a year }\end{array}$ \\
\hline GCB Bank & 9 & 3 & 12 & 9 & Not disclosed \\
\hline Royal Bank & 7 & 1 & 8 & 6 & Not disclosed \\
\hline CAL Bank & 10 & 0 & 10 & 6 & Not disclosed \\
\hline Unique Bank & 5 & 2 & 7 & 5 & Not disclosed \\
\hline UNIBank & 9 & 2 & 11 & 6 & 4 \\
\hline Total & 40 & 8 & 48 & 35 & 4 \\
\hline Diamond Bank & 13 & 3 & 16 & 6 & 6 \\
\hline EcoBank & 9 & 4 & 13 & 8 & 6 \\
\hline Fidelity Bank & 10 & 3 & 15 & 8 & 12 \\
\hline $\begin{array}{l}\text { First City Monumental } \\
\text { Bank }\end{array}$ & 10 & 0 & 10 & 8 & 6 \\
\hline Access Bank & 11 & 5 & 16 & 6 & 6 \\
\hline Total & 53 & 15 & 68 & 36 & 36 \\
\hline
\end{tabular}

\subsection{General Corporate Governance Disclosure of the Banks}

A perfunctory glimpse at Table 2 provides a summary of corporate governance disclosure for Ghanaian and Nigerian banks. The summary of the findings shows that Ghanaian banks, in general, disclose less information than the Nigerian banks. On the whole, the financial reports of Ghanaian banks tend to be much shorter in length than the Nigerian banks, ranging from 80 to 130 pages. The Nigerian banks have more voluminous financial reports which range from 214 to 298 pages. Ghanaian banks appear to disclose less corporate governance information in all six core areas: board structure and director profile, financial information and corporate information, board independence and board committee, corporate social responsibility 
disclosure, information on the website, and remuneration of the board. On closer inspection, we find in Table 3, Ghanaian banks have much lower scores with regards to board structure and director profile. The average score for Ghanaian banks is 7.4, and for financial and corporate information the average score is 7.6. Nigerian banks, on the average, score better than their Ghanaian counterparts with scores of 10.4 and 8.8 for the same indices.

Also, regarding the overall level of corporate governance disclosure, Ghanaian banks tend to have a large disparity between the best performing bank and the worst performing bank. The best performing bank scores an estimated $70.5 \%$, while the worst performing scores $41 \%$. This is not the case for Nigerian banks, while there is some level of the discrepancy; it tends to be much smaller. In the case of Nigerian banks, the best performing bank scored $76.5 \%$, for the worst performing bank the score was $64.7 \%$. The percentage difference between the best and worst-performing bank for Ghana and Nigeria is $29.5 \%$ and $11.8 \%$.

Of recent, there is an increasing level of convergence in corporate governance practices; the intent is to enhance corporate governance practices in developing countries. Ghanaian and Nigerian banks in this study tend to comply with some of these corporate governance principles such as separating the role of the chairman and the chief executive officer, enhancing the independence of the board by having a mix of non-executive directors, and improving transparency and accountability through voluntary disclosure of more information than is mandated by law. While the levels of mandatory corporate governance disclosure for Ghanaian and Nigerian banks can be commended in relation to financial information, there are still areas that can be strengthened. For Ghanaian banks, variation in the levels of disclosure needs to be addressed so that all banks are on par with levels of corporate governance disclosure. For Nigerian banks, the following areas of corporate governance disclosure can be improved upon: the disclosure of remunerations to chief executive officer and other directors, and the degree of independence of directors.

Table 2: Summary of Corporate Governance Disclosure for Ghanaian and Nigerian Banks

\begin{tabular}{|l|l|l|l|l|l|l|l|l|l|l|l|l|}
\hline & BANKS & $\begin{array}{l}\text { Possible } \\
\text { Score }\end{array}$ & $\begin{array}{l}\text { CAL } \\
\text { Bank }\end{array}$ & GCB & $\begin{array}{l}\text { Royal } \\
\text { Exchange }\end{array}$ & $\begin{array}{l}\text { Unique } \\
\text { Bank }\end{array}$ & $\begin{array}{l}\text { Uni } \\
\text { Bank }\end{array}$ & $\begin{array}{l}\text { Diamond } \\
\text { Bank }\end{array}$ & $\begin{array}{l}\text { Fidelity } \\
\text { Bank }\end{array}$ & $\begin{array}{l}\text { Eco } \\
\text { Bank }\end{array}$ & $\begin{array}{l}\text { FCMB } \\
\text { Structure } \\
\text { Profile }\end{array}$ \\
\hline 2 & 12 & 10 & 9 & 6 & 6 & 6 & 11 & 10 & 9 & 11 \\
Bank \\
$\begin{array}{l}\text { Financial } \\
\text { Information } \\
\text { and } \\
\text { corporate } \\
\text { information }\end{array}$
\end{tabular}


Table 3: Descriptive Statistics of Corporate Governance Disclosure for Ghana and Nigerian African Banks

\begin{tabular}{|c|c|c|c|c|c|c|c|c|c|c|c|}
\hline & & \multicolumn{5}{|c|}{ Ghanaian Banks } & \multicolumn{5}{|c|}{ Nigerian Banks } \\
\hline & & Mean & $\begin{array}{l}\text { Standard } \\
\text { Deviation }\end{array}$ & Variance & Maximum & Minimum & Mean & $\begin{array}{l}\text { Standard } \\
\text { Deviation }\end{array}$ & Variance & Maximum & Minimum \\
\hline 1 & $\begin{array}{l}\text { Board } \\
\text { Structure and } \\
\text { Directors } \\
\text { Profile }\end{array}$ & 7.4 & 1.94 & 3.8 & 10 & 6 & 10.4 & 0.89 & 0.8 & 11 & 9 \\
\hline 2 & $\begin{array}{l}\text { Financial } \\
\text { Information } \\
\text { and corporate } \\
\text { information }\end{array}$ & 7.6 & 1.5 & 2.3 & 9 & 6 & 8.8 & 0.83 & 0.7 & 10 & 8 \\
\hline 3 & $\begin{array}{l}\text { Board } \\
\text { Independence } \\
\text { and Board } \\
\text { Committee }\end{array}$ & 5.6 & 1.8 & 3.3 & 8 & 3 & 6 & 0.7 & 0.5 & 7 & 5 \\
\hline 4 & $\begin{array}{l}\text { Corporate } \\
\text { Social } \\
\text { Responsibility } \\
\text { Disclosure } \\
\end{array}$ & 2.4 & 0.89 & 0.8 & 3 & 1 & 3.8 & 0.45 & 0.2 & 4 & 3 \\
\hline 5 & $\begin{array}{l}\text { Information on } \\
\text { website }\end{array}$ & 2.8 & 0.45 & 0.2 & 3 & 2 & 2.6 & 0.54 & 0.3 & 3 & 2 \\
\hline 6 & $\begin{array}{l}\text { Remuneration } \\
\text { of Board }\end{array}$ & 2.8 & 1.09 & 1.2 & 3 & 1 & 3.8 & 0.83 & 0.7 & 5 & 3 \\
\hline
\end{tabular}

Table 4: Critical value tests of corporate governance disclosure in Ghanaian and Nigerian Banks

\begin{tabular}{|c|c|c|c|c|c|c|}
\hline & & $\begin{array}{l}\text { Calculate } \\
\text { d t-values }\end{array}$ & $\begin{array}{l}\text { Critical t- } \\
\text { value } \\
20 \% \text { @d.f. }\end{array}$ & $\begin{array}{l}\text { Criticalt- } \\
\text { value } \\
10 \% \\
8 d . f . \quad @ \\
\end{array}$ & $\begin{array}{l}\text { Critical t- } \\
\text { value } \\
5 \% \text { 8d.f }\end{array}$ & $\begin{array}{l}\text { Decisio } \\
\text { n }\end{array}$ \\
\hline 1 & $\begin{array}{ll}\text { Board } & \text { Structure } \\
\text { and } & \text { Directors } \\
\text { Profile } & \\
\end{array}$ & 3.127716 & 1.39 & 1.86 & 2.31 & $\begin{array}{l}\text { ACCEPT } \\
@ 5 \%\end{array}$ \\
\hline 2 & $\begin{array}{l}\text { Financial } \\
\text { Information and } \\
\text { corporate } \\
\text { information }\end{array}$ & 1.549193 & 1.39 & 1.86 & 2.31 & $\begin{array}{l}\text { ACCEPT } \\
@ 20 \%\end{array}$ \\
\hline 3 & $\begin{array}{l}\text { Board } \\
\text { Independence } \\
\text { and Board } \\
\text { Committee }\end{array}$ & 0.458831 & 1.39 & 1.86 & 2.31 & $\begin{array}{l}\text { REJECT } \\
\text { @ } 20 \%\end{array}$ \\
\hline 4 & $\begin{array}{l}\text { Corporate Social } \\
\text { Responsibility } \\
\text { Disclosure }\end{array}$ & 3.130495 & 1.39 & 1.86 & 2.31 & $\begin{array}{l}\text { ACCEPT } \\
@ 5 \%\end{array}$ \\
\hline 5 & $\begin{array}{l}\begin{array}{l}\text { Information on } \\
\text { website }\end{array} \\
\end{array}$ & 0.632456 & 1.39 & 1.86 & 2.31 & $\begin{array}{l}\text { REJECT } \\
\text { @ 20\% } \\
\end{array}$ \\
\hline 6 & $\begin{array}{l}\text { Remuneration of } \\
\text { Board }\end{array}$ & 1.622214 & 1.39 & 1.86 & 2.31 & $\begin{array}{l}\text { ACCEPT } \\
@ 20 \%\end{array}$ \\
\hline
\end{tabular}

In Table 4, the results of the t-test on the Hypothesis tested in this study are reported for the six hypotheses:

For the first and fourth hypothesis, $\mathrm{H}_{0}{ }^{1}$ : There is no difference in the Board Structure, and Directors Profile disclosure in the annual reports of the Ghanaian and Nigerian banks examined. $\mathrm{H}_{0}{ }^{4}$ : There is no difference in the Corporate Social Responsibility Disclosure in the annual reports of the Ghanaian and Nigerian banks examined. We accept the null hypotheses at the $5 \%$ level of significance as the calculated $t$-value in both cases is higher than the critical value from the table. 
For the second and sixth hypothesis, $\mathrm{H}_{0}{ }^{2}$ : There is no difference in the Financial Information and corporate information disclosure in the annual reports of the Ghanaian and Nigerian banks examined. And $\mathrm{H}_{0}{ }^{6}$ : There is no difference in the Remuneration of Board disclosure in the annual reports of the Ghanaian and Nigerian banks examined We accept the null hypotheses although at a lower level of significance (20\%) as the calculated t-statistics for both hypotheses is higher than the critical t-statistics.

Lastly, for the third and fifth hypothesis; $\mathrm{H}_{0}{ }^{3}$ : There is no difference in the Board Independence and Board Committee disclosure in the annual reports of the Ghanaian and Nigerian banks examined. And $\mathrm{H}_{0}{ }^{5}$ : There is no difference in the Information on website disclosure in the annual reports of the Ghanaian and Nigerian banks examined. We reject the null hypothesis in

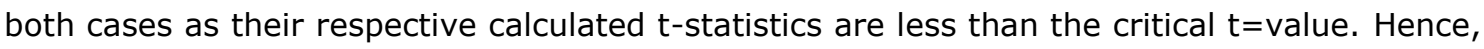
we accept the alternative hypothesis that for third and fifth Hypothesis respectively.

$\mathrm{H}_{1}{ }^{3}$ : There is a significant difference in the Board Independence, and Board Committee disclosure in the annual reports of the Ghanaian and Nigerian banks examined. And for hypothesis $5, \mathrm{H}_{1} 5$ : There is a significant difference in the Information on website disclosure in the annual reports of the Ghanaian and Nigerian banks examined.

\subsection{Board Structure and Directors Profile}

As earlier stated, it is important to have the right mix of executive and non-executive directors on the board. Also, it is equally imperative to ensure that the roles of the chairman and the chief executive officer are not vested in the same person. The codes of corporate governance for Ghana and Nigeria both require that these roles be separated which is in line with global best practice. All Ghanaian and Nigerian banks have complied with this principle of separating the roles of the chairman and chief executive officer. In the board structure and director profile in Table 5, Ghanaian banks scored lower on the average than Nigerian banks. For board structure and director profile, Ghanaian banks scored $65 \%$ while the Nigerian banks scored $91.6 \%$. Poor scores in Ghanaian banks in the disclosure of board structure and director profile were in three areas: a biography of members, information regarding number board members have served their qualification and occupation. For Nigerian banks, the poor scores had to do with disclosure of information of residence of directors; none of the five banks disclosed that information. However, both Ghanaian and Nigerian banks did disclose information on the qualifications, photographs and the duties of the directors.

Table 5: Board Structure and Directors Profile

\begin{tabular}{|l|l|l|l|}
\hline & & Ghanaian & Nigerian \\
\hline 1 & Number of Directors & $5 / 5$ & $5 / 5$ \\
\hline 2 & Duties of Board of Directors & $4 / 5$ & $5 / 5$ \\
\hline 3 & Number of meetings & $1 / 5$ & $5 / 5$ \\
\hline 4 & Chairman Identified & $5 / 5$ & $5 / 5$ \\
\hline 5 & CEO Identified & $5 / 5$ & $5 / 5$ \\
\hline 6 & $\begin{array}{l}\text { Minimum qualifications of } \\
\text { directors }\end{array}$ & $4 / 5$ & $5 / 5$ \\
\hline 7 & Name & $5 / 5$ & $5 / 5$ \\
\hline 8 & Residence & $0 / 5$ & $0 / 5$ \\
\hline 9 & Qualification \& Occupation & $2 / 5$ & $5 / 5$ \\
\hline 10 & Number of years on board & $1 / 5$ & $5 / 5$ \\
\hline 11 & Photos of Members & $5 / 5$ & $5 / 5$ \\
\hline
\end{tabular}




\begin{tabular}{|l|l|l|l|}
\hline 12 & Biography of Members & $2 / 5$ & $5 / 5$ \\
\hline & Percentage of Disclosure & 65 & 91.6 \\
\hline
\end{tabular}

\subsection{Financial and Corporate Information}

In the disclosure of financial and corporation information for Ghanaian and Nigerian banks, the difference in the disclosure can be regarded as marginal with Nigerian banks having a higher score (See Table 6). In the financial and corporation information section, Ghanaian banks have an average score of $63.6 \%$ while the Nigerian banks have an average score of $72.7 \%$. Ghanaian banks recorded poor disclosure in areas relating to information on share price and statements relating to a competitive position regarding industry practices. Nigerian banks also scored poorly on the same indices. On compliance with codes of corporate governance for Ghana and Nigeria, all the banks complied with the mandatory requirements of disclosure of financial information regarding the state of the banks and at least a minimum of two years' summary of financial data. Similarly, in regards to disclosure on bank loans, retained profits, and general information about the economy, Ghanaian and Nigerian banks appeared to have disclosed equal amounts of information.

\subsection{Corporate Social Responsibility Disclosure in Ghanaian and Nigerian Banks}

On matters of corporate social responsibility, neither Ghanaian nor Nigerian regulators have designed any specific legislation. While Ghana may not have any specific corporate social responsibility legislation, it does have relevant statutes and laws that ensure corporations run their businesses in a responsible way. In Nigeria, corporate social responsibility by most multinational firms grew as a result of the youthful restiveness and militancy in the Niger Delta region. Multinational corporations in the region decided to pacify the youths by engaging in communal development projects, providing skill acquisition centres, a building of social infrastructure and providing employment opportunities. The multinational companies, particularly the mining companies, understood that non-financial business risks could significantly disrupt their business activities.

Table 6: Financial information and corporate information

\begin{tabular}{|l|l|l|l|}
\hline & & Ghanaian & Nigerian \\
\hline 1 & $\begin{array}{l}\text { Summary of financial data for at least two } \\
\text { years }\end{array}$ & $5 / 5$ & $5 / 5$ \\
\hline 2 & Share price information & $1 / 5$ & $2 / 5$ \\
\hline 3 & Retained Profits & $5 / 5$ & $5 / 5$ \\
\hline 4 & Bank loans & $5 / 5$ & $5 / 5$ \\
\hline 5 & Foreign currency fluctuation during the year & $3 / 5$ & $4 / 5$ \\
\hline 6 & General information about the economy/ & $3 / 5$ & $3 / 5$ \\
\hline 7 & Corporate mission statement & $3 / 5$ & $3 / 5$ \\
\hline 8 & Business environment (economics, politics) & $5 / 5$ & $5 / 5$ \\
\hline 9 & $\begin{array}{l}\text { Statement disclosure relating to competitive } \\
\text { position in industry }\end{array}$ & $1 / 5$ & $1 / 5$ \\
\hline 10 & Corporate contribution to national economy & $3 / 5$ & $2 / 5$ \\
\hline 11 & Significant issues during the year & $4 / 5$ & $5 / 5$ \\
\hline & Percentage of Disclosure & 63.6 & 72.7 \\
\hline
\end{tabular}

Ghanaian banks in the study have not fully embraced the need for corporate social responsibility, with various Ghanaian banks having a varied approach to the application of corporate social responsibility. Nigerian banks appear to be a bit better in terms of corporate 
social responsibility reporting. All Nigerian banks in the study have sections in their annual report devoted to discussion of corporate social responsibility policy and projects undertaken by the banks. Nigerian banks tend to do better than Ghanaian banks in two areas: statement of corporate social responsibility environmental policy and the disclosure of corporate social responsibility projects undertaken by the banks.

Table 7: Corporate Social Responsibility Disclosures

\begin{tabular}{|l|l|l|l|}
\hline & & Ghanaian & Nigerian \\
\hline 1 & Statement on Corporate Social Responsibility & $5 / 5$ & $5 / 5$ \\
\hline 2 & Statement on Environmental Policy & $0 / 5$ & $4 / 5$ \\
\hline 3 & Environmental Projects/Activities Taken & $3 / 5$ & $5 / 5$ \\
\hline 4 & $\begin{array}{l}\text { Information on community involvement } \\
\text { participation }\end{array}$ & $5 / 5$ & $5 / 5$ \\
\hline & Percentage of Disclosure & 65 & 96 \\
\hline
\end{tabular}

\subsection{Board Independence \& Board Committee and Remuneration of Board}

The independence of the board of directors is an internal check and balance mechanism designed to check if any, the excesses of the chief executive officer and chairman of the board. An independent director is one who is not usually an employee or partner of the business who performs the company's external and internal financial audits. Corporate governance research argues that an independent director is more likely to protect the interest of the shareholders and prevail on managers when they unintentionally or intentionally make decisions that are not in the best interest of the corporation or the shareholders. Again, we find that Ghanaian banks disclose less information on board independence and board committee when compared with Nigerian banks. Ghanaian banks on the average scored $56 \%$ while Nigerian banks scored $72 \%$.

Table 8: Board Independence and Board Committee

\begin{tabular}{|l|l|l|l|}
\hline & & Ghanaian & Nigerian \\
\hline 1 & $\begin{array}{l}\text { Separate Section outlining Board } \\
\text { Independence }\end{array}$ & $0 / 5$ & $2 / 5$ \\
\hline 2 & Separation of the role of Chairman and CEO & $5 / 5$ & $5 / 5$ \\
\hline 3 & $\begin{array}{l}\text { Capable of determining independence of } \\
\text { Board Remuneration Review }\end{array}$ & $2 / 5$ & $0 / 5$ \\
\hline 4 & $\begin{array}{l}\text { Capable of determining independence of } \\
\text { audit committee }\end{array}$ & $5 / 5$ & $5 / 5$ \\
\hline 5 & $\begin{array}{l}\text { Capable of determining independence of } \\
\text { Conduct Review or Risk Committee }\end{array}$ & $1 / 5$ & $2 / 5$ \\
\hline 6 & Number of Committees & $4 / 5$ & $5 / 5$ \\
\hline 7 & Duties of Committees & $4 / 5$ & $4 / 5$ \\
\hline 8 & Number of Meetings & $0 / 5$ & $5 / 5$ \\
\hline 9 & Number of Members & $3 / 5$ & $5 / 5$ \\
\hline 10 & Identify Chairmen & $4 / 5$ & $3 / 5$ \\
\hline & Percentage of Disclosure & 56 & 72 \\
\hline
\end{tabular}

When a comparative assessment of board independence and board committee for Ghanaian and Nigerian banks is made, we find that Ghanaian and Nigerian banks neglect to disclose information on the following indices: board independence with regards to the audit committee, risk committee and a separate section outlining the independence of directors in the annual 
reports. In dealing with the issue of agency costs, aligning the needs of managers and shareholders through attractive remuneration that rewards managers for increasing shareholders' wealth are seen as an internal mechanism for checking the excesses of managers. Underperforming managers are not rewarded and often may lose their jobs when they perform poorly. The opposite also holds true with managers who perform well earning significant pay and share option increases as a result of increasing shareholders' wealth. In Table 9, the corporate governance disclosure pertaining to the remuneration of the board of directors' records poor scores for Ghanaian and Nigerian banks. Ghanaian banks score an estimated 35\%, while Nigerian banks score 52.5\%. Both Ghanaian and Nigerian banks recorded poor scores with regards to the following issues: an explanation of chief executive officers' stock requirement, loans to chief executive officers, explanation of directors' stock requirement and loans to directors.

\subsection{Corporate Governance Voluntary Disclosure of Ghanaian and Nigerian banks}

Voluntary corporate governance disclosure is an informative guide to the level of corporate governance disclosure of a firm. As it stands, there is significant research evidence to maintain that there is a link between the voluntary corporate governance disclosure practices of a firm and its ability to raise capital. Consequently, firms which disclose more information are more likely to find it easier to access and raise capital. In deciding which corporate governance disclosure issue on the coding sheet was obligatory and which was not, an examination of disclosure requirements for the Ghanaian Stock Exchange, Ghana Companies Code, Nigerian Stock Exchange, Corporate Matters Allied Act, and Corporate Governance Codes for Nigerian Banks was undertaken.

Table 9: Remuneration of Board

\begin{tabular}{|l|l|l|l|}
\hline & & Ghanaian & Nigerian \\
\hline 1 & CEO Salary & $0 / 5$ & $4 / 5$ \\
\hline 2 & Number of shares owned by CEO & $4 / 5$ & $4 / 5$ \\
\hline 3 & Explanation of CEO stock requirement & $0 / 5$ & $0 / 5$ \\
\hline 4 & Loans to CEO & $0 / 5$ & $0 / 5$ \\
\hline 5 & Directors salary & $5 / 5$ & $4 / 5$ \\
\hline 6 & Number of shares owned by directors & $4 / 5$ & $5 / 5$ \\
\hline 7 & Explanation of directors' stock requirements & $0 / 5$ & $0 / 5$ \\
\hline 8 & Loans to directors & $1 / 5$ & $2 / 5$ \\
\hline & Percentage of Disclosure & 35 & 52.5 \\
\hline
\end{tabular}

Of the 51 items listed on the corporate governance disclosure sheet, 19 of the items can be regarded as voluntary corporate governance disclosure items. In Table 10, a list of the voluntary corporate governance items has been listed. The results of the voluntary corporate governance show that Ghanaian banks disclose less information than Nigerian banks. Ghanaian banks scored $24.2 \%$ while the Nigerian banks scored $34.2 \%$. The poor voluntary disclosure appears to be an issue for both Ghanaian and Nigerian banks. On particular voluntary corporate governance issues, Ghanaian and Nigerian banks score zero: number of directors that can sit on and outside the board, past committee experience, the number of related directors, explanation of director stock requirements', explanation of chief executive officers' stock requirement and information on residence of directors. 
Table 10: Voluntary Governance Disclosure for Ghanaian and Nigerian Banks

\begin{tabular}{|l|l|l|l|}
\hline & Voluntary Information Disclosed & Ghanaian & Nigerian \\
\hline 1 & Residence & $0 / 5$ & $0 / 5$ \\
\hline 2 & Occupation & $4 / 5$ & $5 / 5$ \\
\hline 3 & Number of years on Board & $1 / 5$ & $5 / 5$ \\
\hline 4 & $\begin{array}{l}\text { Capable of determining independence of board } \\
\text { remuneration review }\end{array}$ & $2 / 5$ & $0 / 5$ \\
\hline 5 & $\begin{array}{l}\text { Capable of determining independence of conduct } \\
\text { review or risk committee }\end{array}$ & $1 / 5$ & $2 / 5$ \\
\hline 6 & Photos of members & $5 / 5$ & $5 / 5$ \\
\hline 7 & Biography of Members & $2 / 5$ & $5 / 5$ \\
\hline 8 & Explanation of CEO Stock Requirement & $0 / 5$ & $0 / 5$ \\
\hline 9 & Explanation of director Stock Requirement & $1 / 5$ & $5 / 5$ \\
\hline 10 & Number of related directors & $0 / 5$ & $0 / 5$ \\
\hline 11 & Reasons for relations & $0 / 5$ & $0 / 5$ \\
\hline 12 & Online link to Corporate Governance Web page & $3 / 5$ & $5 / 5$ \\
\hline 13 & Number of affiliates & $0 / 5$ & $0 / 5$ \\
\hline 14 & Reason of affiliation & $0 / 5$ & $0 / 5$ \\
\hline 15 & Past Committee experience & $0 / 5$ & $0 / 5$ \\
\hline 16 & $\begin{array}{l}\text { Separate Section outlining board independence } \\
\text { criteria }\end{array}$ & $0 / 5$ & $2 / 5$ \\
\hline 17 & Online histogram of organization & $0 / 5$ & $0 / 5$ \\
\hline 18 & Minimum qualification for directors & $4 / 5$ & $5 / 5$ \\
\hline 19 & $\begin{array}{l}\text { Number of directors that can sit on and outside the } \\
\text { board }\end{array}$ & $0 / 5$ & $0 / 5$ \\
\hline & Percentage of Disclosure & $24.2 \%$ & $34.5 \%$ \\
\hline
\end{tabular}

\section{SUMMARY AND CONCLUSION}

In concluding, we accept that there is no significant difference in disclosure for Ghanaian and Nigerian banks on the following issues: board structure and director profile; financial information and corporation information; corporate social responsibility disclosure and remuneration of the board. However, we do reject the null hypothesis with regards to the following issues: board independence and board committee, and information on websites. On these two issues, Ghanaian banks tend to disclose less information than Nigerian banks. The research findings in this paper are consistent with prior research works on corporate governance on Ghana and Nigeria. Prior research with regards to corporate governance disclosure, has found modest levels of disclosure for Ghanaian listed companies. For Ghana, Agyei-Mensah (2012) finds that Ghanaian listed firms scored 60.9\% which is slightly higher than the $56.4 \%$ for Ghanaian banks in the study. In the case of Nigeria, Isukul and Chizea (2016) find a disclosure score of $72.9 \%$, which is almost equivalent to $70.2 \%$ for Nigerian banks in the study. The results are also consistent with findings of voluntary corporate governance research in developing countries. The voluntary disclosure scores for developing countries are as follows: for Egypt, the disclosure score is 13.4\% (Samaha\&Dahawy 2011); for Kuwait, the disclosure score is 19\% (Al-Shammari\& Al-Sutan, 2010); for Ghana, the disclosure is 35\% (Agyei-Mensah, 2015) and the disclosure for Nigerian listed firms is $44 \%$ (Humayan\&Adelopo, 2012). Also, Kenyan firms recorded low levels for voluntary corporate governance disclosure (Barroko et al., 2006).

While the disclosure scores on voluntary corporate governance can be regarded as poor, however, there is a particularly positive trend regarding voluntary corporate governance reporting. Ghanaian banks and Nigerian banks are increasing the level of transparency, and the amount of voluntary information disclosed in the annual reports. The compliance with international financial standard reporting, along with the introduction of corporate governance codes in Ghanaian and Nigerian banks, could be seen as a convergence of practice which is 
improving corporate governance disclosure in developing countries. Developing countries are benefiting immensely from technological platforms such as the internet which allows them to upload electronic copies of their annual reports online. Although the results are far from satisfactory, they are a step in the right direction as improvements to the voluntary disclosure can be made. As such, policymakers and regulators should begin to consider measures and incentives that can be used to encourage firms to enhance their voluntary corporate governance disclosure.

Also, another issue of concern for policy makers and regulators is the lack of gender diversity in Ghanaian and Nigerian banks as the board of directors of these banks tend to be maledominated. While this should not come as a surprise, research on gender diversity maintains that firms with a more diverse board are more likely to have better financial performance. Consequently, it would be suggested that developing countries should become gender sensitive and find ways for the inclusion of more women in the boardrooms since their presence could be of immense benefit to the firm. Although this research has investigated corporate governance disclosure in Ghanaian and Nigerian banks, there is the need for further research. The sample size of this research is considerably small, and its findings cannot be generalized. It would be interesting to see if the inclusion of more firms in Ghana and Nigeria would yield similar results or different results entirely. In that respect, it would be important to expand the sample size for both Ghanaian and Nigerian Banks. In addition, it would be fascinating to examine other African countries to find out if their corporate governance disclosures are similar to those that have been examined in this study.

\section{REFERENCES}

- Abdelkarim, N., Shahin, Y.A, and Arqawi, B.M. (2009) "Investors perception of information disclosed in financial report of Palestine security listed exchange companies", Accounting and Taxation, Vol. 1, No. 1, pp. $45-62$.

- Abdioglu, N., Bamiatzi, V., Cavusgil, S. T., Khurshed, A., \& Stathopoulos, K. (2015) "Information asymmetry, disclosure and foreign institutional investment: An empirical investigation of the impact of the Sarbanes-Oxley Act", International Business Review, 24, 902-915, CrossRef

- Abor, J., \&Adjasi, C. K. (2007). "Corporate governance and the small and medium enterprises sector: theory and implications", Corporate Governance: The international journal of business in society, 7(2), 111-122, CrossRef

- Adegbite, E. (2015) "Good corporate governance in Nigeria: Antecedents, propositions and peculiarities", International Business Review, 24(2), 319-330, CrossRef

- Adegbite, E. \& Nakajima, C. (2012) "Institutions and institutional maintenance: implications for understanding and theorizing corporate governance in developing economies", International Studies of Management and Organization, Vol. 42, No. 3, 69-88, CrossRef

- Adegbite, G.O. (2012) "Corporate governance development in Ghana", Public and Municipal Finance, 1(2), 71-75.

- Adekoya, A. A. (2011) "Corporate Governance Reforms in Nigeria: Challenges and Suggested Solutions," Journal of Business Systems, Governance and Ethics, Vol. 6. No. 1 , pp. 38-50

- Adhikari, A., and Tondkar, R.H. (1992) 'Environmental factors influencing accounting disclosure requirements of global stock exchanges', Journal of International Financial Management and Accounting, Vol. 4, No. 2, CrossRef

- Agyei-Mensah, B.K. (2015) Internal control information disclosure and corporate governance: evidence from an emerging market. Corporate Governance, 16(1), 7995, CrossRef

- Agyei-Mensah, B.K. (2012) "The impact of adopting international standard accounting standards 1(IAS) in Ghana: The extent of disclosure and their relationship with 
corporate characteristics", African Journal of Business Management, Vol.6 (44), pp. 10896-10905, CrossRef

- Agyemang, O. S., \&Castellini, M. (2013). Corporate governance in an emergent economy: a case of Ghana. IUP Journal of Corporate Governance, 12(3), 7.

- Ahmed, K. And Courtis, J. (1999) "Association between corporate characteristics and disclosure levels in annual reports: a meta-analysis", British Accounting Review, Vol. 31 , pp. 35-61, CrossRef

- Ahunwan, B. (2002) "Corporate governance in Nigeria". Journal of Business Ethics, Vol. 37, Is. 3, pp. 269-287, CrossRef

- Ajinkya, B., Bhojraj, S., \&Sengupta, P. (2005). The association between outside directors, institutional investors and the properties of management earnings forecasts. Journal of accounting research, 43(3), 343-376, CrossRef

- Akhtaruddin, M. (2005) "Corporate disclosure practices in Bangladesh", International

- Al-Shammari, B., \& Al-Sultan, W. (2010). Corporate governance and voluntary disclosure in Kuwait. International Journal of Disclosure and Governance, 7(3), 262280, CrossRef

- Arvidsson, S. (2003) "Disclosure of non-financial information in the annual report: a management perspective", Journal of Intellectual Capital, Vol. 12, No. 2, pp. 277-300, CrossRef

- Ayittey, G. (1998) Africa in chaos, New York: St Martin's Press.

- Barako, D.G. (2007) Determinants of voluntary disclosure in Kenyan companies annual reports. African Journal of Business Management, 1(5), 113-128.

- Barako, D.G., Hancock, P., Izan, I.H.Y. (2006). Factors influencing voluntary corporate disclosure by Kenyan companies. Corporate Governance: An International Review $14: 2,107-125$, CrossRef

- Beekes, W. and Brown, P. (2006) "Do better-governed Australian firms make more informative disclosures?", Journal of Business Finance and Accounting, Vol. 33, No. 3/4, pp. 422-450, CrossRef

- Berglöf, E., \&Thadden, V. (1999). The changing corporate governance paradigm: implications for transition and developing countries. In Conference Paper, Annual World Bank Conference on Development Economics, Washington DC.

- Bhasin, M. (2010) "Corporate governance disclosure Practices: The Portrait of a Developing Country", International Journal of Business and Management, Vol. 5, No. 4, pp. 150-167, CrossRef

- Bhasin, M. (2013) Voluntary corporate governance disclosure in the annual reports. International Journal of Finance and Accounting, 2(4), 199-210.

- Blair, M. M. (1995). Rethinking assumptions behind corporate governance. Challenge, $38(6), 12-17$, CrossRef

- Boatright, J.R. (1999). Ethics in finance, Blackwell, Oxford, CrossRef

- Bosse, D., Phillips, R., \& Harrison, J. (2009). Stakeholders, reciprocity, and firm performance. Strategic Management Journal, 30(4), 447-456, CrossRef

- Brennan, N. and Solomon, J. (2008) "Corporate governance, accountability and mechanisms of accountability: an overview", Accounting, Auditing and AccountabilityJournal, 21(7), 885-906, CrossRef

- Buzby, S.L. (1974) "Selected items of information and their disclosure in annual reports", The Accounting Review 49(3), 423-435.

- Cadbury, A. (2002). Corporate governance and chairmanship: A personal view. Oxford University Press on Demand, CrossRef

- Cheng, E.C.M. and Courtenay, S.M. (2006), "Board composition, regulatory regime and voluntary disclosure", The International Journal of Accounting, 41(3), 262-289, CrossRef

- Claessens, S. (2006). Corporate governance and development. The World Bank Research Observer, 21(1), 91-122, CrossRef 
- Claessens, S., \& Fan, J. P. (2002). Corporate governance in Asia: A survey. International Review of finance, 3(2), 71-103, CrossRef

- Collett, P., \&Hrasky, S. (2005). Voluntary disclosure of corporate governance practices by listed Australian companies. Corporate Governance: An International Review, 13(2), 188-196, CrossRef

- Cohen, J., G. Krishnamoorthy, and A. M. Wright. (2007) The impact of roles of the board on auditors' risk assessments and program planning decisions. Auditing: A Journal of Practice \& Theory 26 (1): 91-112, CrossRef

- Cooke, T.E. (1989) "Disclosure in corporate annual reports of Swedish companies", Accounting Journal of Business Research, 19, 113-124, CrossRef

- Core, J. E., Hail, L., \& Verdi, R. S. (2015). Mandatory disclosure quality, inside ownership, and costof capital. European Accounting Review, 24(1), 1-29, CrossRef

- Donaldson, L \& Davis, J.H. (1991) "Stewardship theory or agency theory: CEO governance and shareholder returns", Australian Journal of Management, 16(1), 4965, CrossRef

- Elshandidy, T., \&Neri, L. (2015). Corporate governance, risk disclosure practices, and market liquidity: Comparative evidence from the UK and Italy. Corporate Governance: An International Review, 23(4), 331-356, CrossRef

- Eisenhardt, K.M. (1989) 'Agency Theory: An assessment and review' The Academy of Management Review, 14(1), 57-74, CrossRef

- Elmagrhi, Mohamed H., Ntim, Collins G. and Wang, Yan (2016) Antecedents of Voluntary Corporate Governance Disclosure: A Post-2007/08 Financial Crisis Evidence from the Influential UK Combined Code. Corporate Governance, 16 (3), CrossRef

- Eng, L. L., \&Mak, Y. T. (2003) "Corporate governance and voluntary disclosure", Journal of accounting and public policy, 22(4), 325-345, CrossRef

- Fama, F. E. and C. M. Jensen (1983)."Agency problems and residual Claims." The Journal of Law and Economics 26(2): 327-357, CrossRef

- Freeman, R. E. (2010). Managing for stakeholders: Trade-offs or value creation. Journal of Business Ethics, 96, 7-9, CrossRef

- Gomez-Meija, L. R. and R. M. Wiseman (2006). "Does agency theory have universal relevance?" Journal of Organizational Behaviour 28(1): 81-88, CrossRef

- Gray, S. J., Meek, G. K., and Roberts, C. B. (1995) "International capital market pressures and voluntary annual report disclosures by U.S. and U.K. multinationals", Journal of International Financial Management and Accounting, 6(1): 43-68, CrossRef

- Gul, F. A., \& Leung, S. (2004). Board leadership, outside directors' expertise and voluntary corporate disclosures. Journal of Accounting and public Policy, 23(5), 351379, CrossRef

- Guilding, C., Warnken, J., Ardill, A., and L. Fredline (2005). "An agency theory perspective on owners/managers relationships in tourism based condomiums." Tourism Management 26: 409-420, CrossRef

- Gunu, U. (2009). The impact of banking industry recapitalization on employment in Nigerian Banks. European Journal of Social Sciences. 11(3): $486-495$

- Haniffa, R. and Cooke, T.E. (2002) "Culture, corporate governance and disclosure in Malaysian corporations", Abacus, 3, 317-349, CrossRef

- Healy, P.M. and Palepu, K.G. (2001), "Information asymmetry, corporate disclosure, and the capital markets: A review of the empirical disclosure literature", Journal of Accounting and Economics, 31, 405-440, CrossRef

- Hill, C.W. \& Jones, T.M. (1992) "Stakeholder-agency theory", Journal of Management Studies, 29, 134-154, CrossRef

- Hope, O. K. (2003). Disclosure practices, enforcement of accounting standards, and analysts' forecast accuracy: An international study. Journal of accounting research, 41(2), 235-272, CrossRef 
- Humayun, K. \&Adelepo, I. (2012) "Corporate governance disclosure practices by Swaziland public enterprises", African Journal of Business and Management, 6(24), 7136-7148.

- Isukul, A. and Chizea, J. (2015) Environmental influences of corporate governance: the Nigerian reality, Sage Open, 5(2), 1-11, CrossRef

- Isukul, A. and Chizea, J. (2016) Institutional governance reform: examining the case of ECOWAS. Asian Research Journal of Arts and Social Science, 1(4), 1-12, CrossRef

- Jensen, C.M. \&Meckling, W.H. (1976) 'Theory of the firm: managerial Behaviour, agency costs and ownership' Journal of Financial Economics, 3, 305-360, CrossRef

- Kyereboah-Coleman, A. \&Biekpe, N. (2008) The Relationship Between Board Size, Board Composition, CEO Duality and Firm Performance: Experience from Ghana. Corporate Ownership and Control 4(2).

- 58.LaPorta, R. Lopez-de-Silanes, F. Shleifer, A and Vishny, R. (2000) "Investor Protection and Corporate Governance". Journal of Financial Economics, 58, 3-27, CrossRef

- Lambert, R., Leuz, C. and Verrecchia, R. (2007) Accounting information, disclosure, and the cost of capital, Journal of Accounting Research, 45(2), 385-420, CrossRef

- Maingot, M. and Zeghal, D. (2008) "An analysis of corporate governance information disclosure by Canadian banks", Corporate Ownership and Control, 5(2), 225-236, CrossRef

- Marston, C. L. \& Shrives, P.J. (1991) "The use of disclosure indices in accounting research: a review article", British Accounting Review 23(3), 195-210, CrossRef

- McGee, R. W. (2010). Corporate Governance in Transition and Developing Economies: A Case Study of Peru. Available at SSRN 1665964, CrossRef

- Ntim, C.G. (2015). Board diversity and organizational valuation: Unravelling the effects of ethnicity and gender. Journal of Management \& Governance, 19, 167-195, CrossRef

- Ntim, C. G., Opong, K. K., Danbolt, J., \& Thomas, D. A. (2012). Voluntary corporate governance disclosures by post-apartheid South African corporations. Journal of Applied Accounting Research, 13(2), 122-144, CrossRef

- Ogbeche, C and Koufopoulos D.N (2007) Board effectiveness in the Nigerian Banking industry, working paper Pan African University Lagos Nigeria and Brunel University London.

- Okeahalam, C. C., \&Akinboade, O. A. (2003). A review of corporate governance in Africa: Literature, issues and challenges. In global corporate governance forum, 15, $1-34$.

- Okike, E.N. (2007) "Corporate Governance in Nigeria: The Status Quo". Corporate Governance: An International Review, 15(2), 173-193, CrossRef

- Okpara, J. (2009) "Corporate governance in a developing economy: barriers, issues and implications for the firms", Corporate Governance, 11(2), 184-199, CrossRef

- Oluwagbemiga, E.O. (2014) "The use of voluntary disclosure in determining the quality of financial statements: evidence from Nigerian listed companies", Serbian Journal of Management, 9(2), 263-280, CrossRef

- Oman, C., Fries, S. \&Buiter, W. (2003) Corporate governance in developing, transition and emerging markets. OECD development center policy brief 23.

- Oyejide, A. T., \&Soyibo, A. (2001). "Corporate governance in Nigeria". Paper presented at the Conference on Corporate Governance, Accra, Ghana 29-30, January

- Patel, S. A. and Dallas, G. (2002) Transparency and Disclosure: Overview of Methodology and Study Results. United States: Standard \& Poor's European Corporate Governance Institute, October 2002.

- Philips, R. (2003). Stakeholder Theory and Organizational Ethics. San Francisco: Berret Kohler Publishers, Inc.

- Radebaugh, L. H., and Gray, S.J. (1993) International Accounting and Multinational Enterprises, John Wiley \& Sons, 1993. 
- Reynolds, S., Schultz, F. \&Hekman, D. (2006) "Stakeholder theory and managerial decision-making: constraints and implications of balancing stakeholder interests", Journal of Business Ethics, 64(3), 285-301, CrossRef

- Rwegasira, K. (2000). Corporate governance in emerging capital markets: whither Africa?.Corporate Governance: An International Review, 8(3), 258-267, CrossRef

- Samaha, K., \&Dahawy, K. (2011). An empirical analysis of corporate governance structures and voluntary corporate disclosure in volatile capital markets: The Egyptian experience. International Journal of Accounting, Auditing and Performance Evaluation, 7(1-2), 61-93, CrossRef

- Samaha, K., Dahawy, K., Hussainey, K., \& Stapleton, P. (2012). The extent of corporate governance disclosure and its determinants in a developing market: The case of Egypt. Advances in Accounting, 28, 168-178, CrossRef

- Scaltrito, D. (2015). Assessing disclosure quality: A Methodological Issue. Journal of Modern Accounting and Auditing, 11(9), 466-475, CrossRef

- Schotter, A. and K. Weigelt (1992)."Behavioural consequences of corporate incentives and long-term bonuses." Management Science, 26, 183-199.

- Singh, A. (2003). Competition, corporate governance and selection in emerging markets. The Economic Journal, 113(491), CrossRef

- Soludo C.C. (2006) Can Nigeria be the China of Africa? Being a lecture delivered at the Founder's Day of the University of Benin, Nigeria; Nov. 23.pp. 10.

- Solomon, A. (2010). Corporate governance and accountability. London, John Wiley \& Son.

- Strand, R., \& Freeman, R. E. (2015). Scandinavian cooperative advantage: The theory and practice of stakeholder engagement in Scandinavia. Journal of business ethics, 127(1), 65-85, CrosRef

- Tsamenyi M, Enninful-Adu E, Onumah J (2007). "Disclosure and corporate governance in developing countries: evidence from Ghana", Managerial Auditing Journal, 22(3), 319-334, CrossRef

- Uchendu, O. A. (2005) "Banking sector reforms and banking consolidation: The Malaysian experience in banking sector reforms and banking consolidation", Central Bank of Nigeria Publication, 29(2).

- United Nations (2006). Guidance on good practices in corporate governance disclosure United Nations Conference on Trade and Developments. New York -Geneva.

- Wallace, R. S. O. (1988). Corporate financial reporting in Nigeria. Accounting and Business Research, 18 (72), 352-362, CrossRef

- West, A. (2006) "Theorising South Africa's corporate governance", Journal ofBusiness Ethics, 68, 433-448, CrossRef

- Yakasai, G.A (2001) "Corporate Governance in a Third World Country with Particular Reference to Nigeria". Corporate Governance: An International Review, 9(3), 238-253, CrossRef

- Young, J. (2010) "Corporate governance and risk management: a South African perspective", Corporate Ownership and Control, 7(3), 136-145, CrossRef 